\title{
SEDATIVE, ANALGESIC AND CLINICO-BIOCHEMICAL EFFECTS OF ROMIFIDINE IN DONKEYS
}

\author{
Abdel-Wahed RE, Abo-Ghanema I*, Nouh SR, Kenawy AA and Kassem MM
}

(Dept. of Surgery, Fac. Vet. Med., Alex. Univ., and

*Dept. of Physiology, Fac. Vet. Med., Damanhour branch)

\begin{abstract}
Romifidine (ROMI), an $\alpha_{2}$ - adrenergic agonist has been used in different animal species, but its clinical use for donkey surgery is not well documented. The purpose of this study was to evaluate clinically the sedative, analgesic and biochemical effects of ROMI in donkeys undergoing surgical operation. Ten clinically healthy donkeys weighing between 150 and $250 \mathrm{kgs}$, and aging between 4 and 7 years old were used in this investigation. The recommended dose was 80 $\mu \mathrm{g} / \mathrm{kg}$ of romifidine $\mathrm{HCl}$, diluted in $4 \mathrm{ml}$ saline and administered intravenously in donkeys undergoing castration prior animal preparation for aseptic surgery. Sedative, analgesic and clinicobiochemical effects were recorded at 0 (base value) and 15, 45, 75 and $120 \mathrm{~min}$. post ROMI injection. Sedation was determined by the changes in animal behavior after drug administration. Onset and duration of analgesia was assessed using pin pricking. Respiratory rate $(R R)$, rectal temperature $(R T)$ and pulse rate $(P R)$ were also recorded. Blood samples were collected at the same intervals for hemato-biochemical analysis. Descriptive statistical analysis was performed. Sedation was proved in all donkeys characterized by drooping in head and neck, relaxation of lower lip with great reduction of eye alertness within two minutes and lasted for $86.33 \pm$ $0.88 \mathrm{~min}$. It was enough to handle and prepare the animal for aseptic castration. Analgesia with ROMI occurred at $2.0 \pm 0.54 \mathrm{~min}$. and persisted for $68.33 \pm 4.40 \mathrm{~min}$. Slight ataxia was observed in three donkeys during standing, characterized by reduction in co-ordination. Salivation and urination were recorded. No significant changes were revealed in clinical or hemato-biochemical findings except significant decrease in creatinine and significant hyperglycemia during the period of the experiment. It was concluded that ROMI $(80 \mu \mathrm{g} / \mathrm{kg})$ proved as an effective sedative and analgesic and used safely for undertaking elective surgery in donkeys.
\end{abstract}




\section{INTRODUCTION}

In veterinary practice, the major $\alpha_{2}$ agonists are xylazine, detomidine, medetomidine and romifidine. The major actions and side effects are similar although there are, may be, differences in length of action, and in the extent and significance of some side effects (Hall and Clarke, 1991). Chemical restraint drugs i.e. sedatives, have been used in veterinary medicine for over three decades. During this time, several drugs have been introduced; xylazine was synthesized in 1962, as a sedative purely intended for animals and has become one of the sedatives most widely used in veterinary practice (Vainio, 1985). Later on further efforts by chemists and pharmacologists resulted in the development of additional $\alpha_{2}$-adrenergic molecules including detomidine, medetomidine and romifidine. Romifidine (2-bromo-fluoro-2-imidazolidinhylidenebenzamine) is potent $\alpha_{2}$ agonist that produces pharmacologic effect typical for this group of drugs and characterized by sedation, muscle relaxation, reluctance to move, reduced responsiveness to environmental stimuli, bradycardia, decreased cardiac output and reduced respiratory rate (Freeman et al., 2002). Romifidine is potent and selective $\alpha_{2}$ agonists, has been used recently for both sedation and premedication (Voeglti, 1988). Romifidine, a new $\alpha_{2}$ agonist has become available and it is claimed that doses of 40, 80 and $120 \mu \mathrm{g} / \mathrm{kg}$ provide light, deep and deep prolonged sedation. Significant levels of ataxia were observed (Hamm et al., 1995 and Mohsen et al., 2007). Maximum sedation with romifidine was achieved with IV doses of $80 \mu \mathrm{g} / \mathrm{kg}$ in horses (Hall and Clarke, 1991). Romifidine was recently used spinally alone in female 
goats (Amarpal et al., 2002), in combination with morphine spinally in cattle (Fierheller et al., 2004), parentrally alone in cats (Selmi et al., 2004) and with lidocaine in goats (Kinjavdekar et al., 2006). Donkeys may metabolize some drugs faster than horses, which will affect anesthetic duration (Matthew et al., 1997). The present study aimed to evaluate clinically the sedative, analgesic and biochemical effects of ROMI given intravenously in donkeys.

\section{MATERIALS AND METHODS}

The present study was performed on ten apparently healthy donkeys (aging 4 - 7 years and weighing 150 - $250 \mathrm{kgs}$ ). Romifidine hydrochloride (Sedivet, Boehringer ingelheim Vet medica, Inc., Saint Jseph, Mo, USA, 2-bromo-6-floro-2-midazolinnhylidene-Benzamine monohydrochloride) was given by intravenous route in jugular vein. 80 $\boldsymbol{\mu g} / \mathbf{k g}$ of ROMI was selected as a recommended dose diluted in $4 \mathrm{ml}$ saline, according to Hall and Clarke (1991), England et al. (1992), Freeman and England (2000) and Nouh and Abdel-Wahed (2000). Signs, onset, degree and duration of sedation were assessed depending on the behavioral changes. Onset and duration of analgesia were determined according to response to a standard painful stimulus by pin pricking. Respiratory rate $(\mathrm{RR})$, rectal temperature $(\mathrm{RT})$ and pulse rate $(\mathrm{PR})$ were determined and recorded 5 minutes before injection and repeated at 15 , 45, 75 and 120 minutes post injection. Blood samples were collected from jugular vein at the same previous intervals for haematological and biochemical analysis, including values of hemoglobin ( $\mathrm{Hb} \%)$, heamatocrite (PCV \%) and differential leukocytic count (DLC \%) according to Dacia and Lewis (1975). Glucose concentration was $\overline{\text { Kafrelsheikh Vet. Med. J. Vol. } 6 \text { No. } 1 \text { (2008) }}$ 
assessed according to Dubowski (1962). Creatinine was assessed according to Faulkner and King (1976). Urea was assessed according to Fawcett and Scott (1960). Meanwhile, Aspartate transaminase (AST) and Alanin transaminase (ALT) were assessed according to Reitman and Frankel (1957). Statistical analysis of the collected data was carried out using the analysis of variance procedure of the Statistical Analysis System computer package (SAS, 1987).

\section{RESULTS}

\section{Sedative and analgesic effects:}

Signs of sedation and analgesia were observed in all animals post ROMI injection. Signs of Sedation included; reduced awareness of the environment, relaxation of penis and anal sphincter, frequent urination and watery salivation, decrease in frequency and velocity of movement, lowering of head and neck (Fig., 1), dropping of ear, reduced eye alertness and extreme lip separation after $1.16 \pm 0.44 \mathrm{~min}$ post ROMI injection and continued for $86.33 \pm 0.88 \mathrm{~min}$ (table, 1). Ataxia was slightly observed characterized by swaying and leaning on stanchion with flexion of all joints of hind limbs and the animal has a tendency to fall down (Fig., 1). The analgesic effect of ROMI appeared after $2.00 \pm$ $0.54 \mathrm{~min}$. and persisted for $68.33 \pm 4.40 \mathrm{~min}$. (table, 1 ).

\section{Clinico-biochemical effects:}

Changes in values of respiratory rate (RR), rectal temperature (RT) and pulse rate (PR) following IV injection of ROMI are summarized in table (2). Values of $\mathrm{Hb}, \mathrm{PCV}$ and DLC are summarized in table (3). Meanwhile, values of blood glucose, Urea, Creatinine, ALT and AST following IV injection of ROMI are summarized in table (4). 


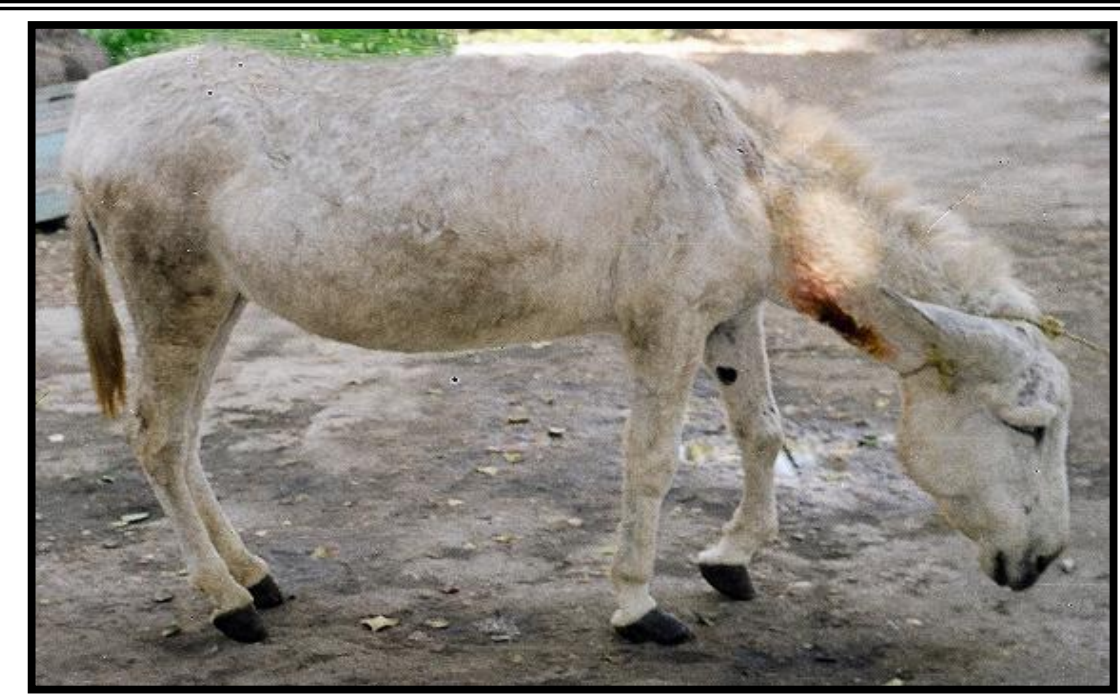

Fig. (1): Showing signs of sedation of 5 years old donkey characterized by drooping of head with a degree of ataxia.

\section{DISCUSSION}

a2-agonists are generally regarded as sedative and hypnotics and are commonly administered to induce sedation. They are also considered a potent analgesic agent, especially in horses. Romifidine, representing $\alpha 2$-agonists binds with and intrinsically changes the membrane of $\alpha 2$ adrenoceptors preventing further release of norepinepherine which is necessary for arousal. If its release is blocked, the net result is sedation (Sinclair, 2003). In this study, rapid onset of sedation (1.16 $\pm 0.44 \mathrm{~min}$.) and longer duration $(86.33 \pm 0.88 \mathrm{~min}$.) following IV injection of ROMI coincided with the findings of Hall and Clarke (1991) and England et al. (1992) who noticed that romifidine has longer duration and maximum sedation than xylazine and detomidine. Greater head lowering may be attributed to excellent muscle relaxation of head and neck followed by dropping of head, neck, ears and lips. This muscle relaxation also resulted in protrusion of penis and relaxation of anal sphincter. Similar 
findings were recorded by Hoffman (1974), Hamm et al. (1995), England and Clarke (1996) and Nouh and Abdel-Wahed (2000). Incidence of ataxia in few cases in this study coincided with the results described by Hall and Clarke (1991), England et al. (1992) and Hamm et al. (1995). On the other hand, Clarke (1988) reported that the degree of ataxia produced with xylazine was more severe. Frequent urination and watery salivation were noticed with similar frequency following romifidine injection. Vainio (1985) obtained the same result. Analgesia produced by intravenously injected ROMI appeared to be most satisfactory. This analgesic effect appeared to be a result of both cerebral and spinal effects, possibly in part mediated by serotonin and the descending endogenous analgesia system (Benson, 1999). Longer duration of analgesia $(68.33 \pm 4.40 \mathrm{mins})$ is referred to that ROMI has longer potency and greater specificity at central $\alpha 2$-adrenoceptor sites (Virtanen and MacDonald, 1985). Hamm et al. (1995) found that romifidine $(20,40$ and $120 \mu \mathrm{g} / \mathrm{kg})$ had no analgesic effect at any of the site stimulated at any time. The sedative effect of $\alpha 2$-agonists appeared to be longer in its duration than analgesic one. Short (1992) advised that the predominant effect of $\alpha 2$-agonists is to produce sedation with associated analgesia. Nilsfors et al. (1989) demonstrated that higher doses of $\alpha 2$-agonists were required to provide analgesia than to provide sedation. Decrease in respiratory rate at $45 \mathrm{~min}$. post injection and pulse rate allover the observation period consistent with England et al. (1992), but not agreed with Nouh and Abdel-Wahed (2000). These differences may be attributed to individual and environmental variations. Reduction in body temperature could be attributed to C.N.S depression in combination with reduction in muscular activity (Virtanen, 1989). On the other hand Sinclair (2003) mentioned that $\alpha 2$-agonists may allow 
better maintenance of body temperature due to peripheral vasoconstriction and central redistribution of the blood with a consequent reduction in cutaneous heat loss. Decrease in pulse rate may be due to induced vagally mediated reflex bradycardia, secondary to increased arterial blood pressure and partly from direct central sympathetic depression (Clarke and Hall, 1969, Kerr et al., 1972, Hall and Clarke, 1991 and Sinclair, 2003). Hall and Clarke (1991) attributed increased urine production following $\alpha 2$-agonists to inhibition of ADH release. Non significant decrease of $\mathrm{Hb}$ was observed post IV injection of Romifidine in donkeys representing the results reported by Vainio (1985). Concerning PCV\%, the result of this study agreed with Wagner et al. (1991) who reported significant reduction in PCV\% in horses. Kumar and Singh (1978) explained the decrease in PCV\% to an increased accumulation of erythrocytes into the spleen by splenic relaxation. Concerning serum analysis, IV injection of Romifidine resulted in significant hyperglycemia. Shokry et al. (1976), Symonds (1976), Symonds and Mallinson (1978) and Hsu and Hammel (1981) attributed this increase to increased hepatic glucose production, hypoinsulinemia or inhibition of insulin release.

Table (1): Showing mean values \pm SE of sedation and analgesia following IV injection of ROMI in donkeys.

\begin{tabular}{|c||c|c|}
\hline Parameter $\backslash$ Time & Onset (min.) & Duration (min.) \\
\hline \hline Sedation & $1.16 \pm 0.44$ & $86.33 \pm 0.88$ \\
\hline Analgesia & $2.00 \pm 0.54$ & $68.33 \pm 4.40$ \\
\hline
\end{tabular}

Number of animals per group $=5$

$\overline{\text { Kafrelsheikh Vet. Med. J. Vol. } 6 \text { No. } 1 \text { (2008) }}$ 
Abdel-Wahed RE et al.,

Table (2): Showing mean values \pm SE of RR, RT and PR following IV ROMI injection in donkeys.

\begin{tabular}{||c||c||c||c||}
\hline Time (min.) & $\begin{array}{c}\text { Respiratory rate } \\
(\mathbf{R R})\end{array}$ & $\begin{array}{c}\text { Rectal } \\
\text { temperature (RT) }\end{array}$ & $\begin{array}{c}\text { Pulse rate } \\
\text { (PR) }\end{array}$ \\
\hline \hline$\underline{\text { Before } 5 \mathrm{~min}}$ & $23.66 \pm 0.88$ & $37.63 \pm 0.14$ & $44.00 \pm 1.15$ \\
\hline$\underline{\text { After }}$ & & & $38.00 \pm 1.15^{*}$ \\
$15 \mathrm{~min}$ & $20.66 \pm 0.88$ & $37.43 \pm 0.14$ & $38.66 \pm 1.45^{*}$ \\
$45 \mathrm{~min}$ & $18.66 \pm 0.88^{*}$ & $36.73 \pm 0.14^{*}$ & $35.66 \pm 1.45^{*}$ \\
$75 \mathrm{~min}$ & $19.00 \pm 0.57$ & $36.63 \pm 0.14^{*}$ & $36.33 \pm 1.45^{*}$ \\
$120 \mathrm{~min}$ & $21.00 \pm .57$ & $36.70 \pm 0.36^{*}$ & \\
\hline
\end{tabular}

* Significantly different to the value before injection $(\mathrm{P}<0.05)$.

Number of animals per group $=5$

Table (3): Showing mean values \pm SE of $\mathrm{Hb}, \mathrm{PCV} \%$ and DLC following IV ROMI injection in donkeys.

\begin{tabular}{|c|c|c|c|c|c|c|}
\hline \multirow{2}{*}{$\begin{array}{l}\text { Time } \\
(\text { min. })\end{array}$} & \multirow{2}{*}{$\begin{array}{c}\text { Hb } \\
\text { (g/dl) }\end{array}$} & \multirow{2}{*}{$\begin{array}{l}\text { PCV } \\
(\%)\end{array}$} & \multicolumn{4}{|c|}{ DLC (\%) } \\
\hline & & & Neutrophil & Eosinophil & Lymphocyte & Monocyte \\
\hline$\frac{\text { Before }}{5 \mathrm{~min}}$ & $\begin{array}{l}9.4 \pm \\
0.05\end{array}$ & $\begin{array}{l}36 \pm \\
0.57\end{array}$ & $46 \pm 0.57$ & $9 \pm 0.57$ & $45 \pm 0.57$ & $3 \pm 0.57$ \\
\hline $\begin{array}{l}\text { After } \\
15 \mathrm{~min} \\
45 \mathrm{~min} \\
75 \mathrm{~min} \\
120 \mathrm{~min}\end{array}$ & $\begin{array}{c}8.6 \pm \\
0.05^{*} \\
8.9 \pm \\
0.05^{*} \\
9.2 \pm \\
0.05 \\
9.4 \pm \\
0.05\end{array}$ & $\begin{array}{c}30 \pm \\
0.59 * \\
29 \pm \\
0.58 * \\
28 \pm \\
0.57 * \\
32 \pm \\
0.52\end{array}$ & $\begin{array}{c}37 \pm 0.59^{*} \\
34 \pm 0.57^{*} \\
37 \pm 0.55^{*} \\
41 \pm 0.51\end{array}$ & $\begin{array}{c}4 \pm 0.47 * \\
2.3 \pm 0.37 * \\
3 \pm 0.54 * \\
7 \pm 0.58\end{array}$ & $\begin{array}{l}41 \pm 0.37 \\
45 \pm 0.55 \\
37 \pm 0.58^{*} \\
37 \pm 0.57^{*}\end{array}$ & $\begin{array}{l}4 \pm 0.50 \\
2 \pm 0.55 \\
4 \pm 0.54 \\
3 \pm 0.47\end{array}$ \\
\hline
\end{tabular}

* Significantly different to the value before injection $(\mathrm{P}<0.05)$.

Number of animals per group $=5$

$\overline{\text { Kafrelsheikh Vet. Med. J. Vol. } 6 \text { No. } 1 \text { (2008) }}$ 
Sedative, Analgesic And Clinico-Biochemical Effects of ...

Table (4): Mean values \pm SE of Glucose, Urea, Creatinine, ALT and AST following IV ROMI injection in donkeys

\begin{tabular}{|c|c|c|c|c|c|}
\hline $\begin{array}{l}\text { Time } \\
(\min )\end{array}$ & $\begin{array}{l}\text { Glucose } \\
\text { (mg/dl) }\end{array}$ & $\begin{array}{c}\text { Urea } \\
(\mathrm{mg} / \mathrm{dl})\end{array}$ & $\begin{array}{c}\text { Creatinine } \\
\text { (mg/dl) }\end{array}$ & $\begin{array}{l}\text { ALT } \\
(\mathbf{u} / \mathbf{l})\end{array}$ & $\begin{array}{l}\text { AST } \\
(\mathbf{u} / \mathbf{l})\end{array}$ \\
\hline Before & & & & & \\
\hline $5 \mathrm{~min}$ & $75 \pm 0.56$ & $30 \pm 0.57$ & $0.90 \pm 0.047$ & $17 \pm 0.77$ & $85 \pm 0.56$ \\
\hline$\underline{\text { After }}$ & \multirow{5}{*}{$\begin{array}{l}105 \pm \\
0.58^{*} \\
120 \pm \\
0.56^{*} \\
135 \pm \\
0.50^{*}\end{array}$} & \multirow{4}{*}{$\begin{array}{r}32 \pm 0.67 \\
29 \pm 0.59 \\
34 \pm \\
0.50\end{array}$} & \multirow{3}{*}{$\begin{array}{c}0.50 \pm \\
0.06^{*}\end{array}$} & \multirow{6}{*}{$\begin{array}{l}10 \pm 0.59 * \\
14 \pm 0.51 \\
14 \pm 0.53 \\
15 \pm 0.55\end{array}$} & \multirow{6}{*}{$\begin{array}{c}84 \pm 0.59 \\
95 \pm 0.50 * \\
83 \pm 0.67 \\
94 \pm 0.37 *\end{array}$} \\
\hline $15 \mathrm{~min}$ & & & & & \\
\hline $45 \mathrm{~min}$ & & & & & \\
\hline $75 \mathrm{~min}$ & & & $\begin{array}{c}0.52 \pm \\
0.05^{*}\end{array}$ & & \\
\hline $120 \mathrm{~min}$ & & \multirow[t]{2}{*}{$28 \pm 0.53$} & $\begin{array}{l}0.62 \pm \\
0.05^{*}\end{array}$ & & \\
\hline & $\begin{array}{l}140 \pm \\
1.15^{*}\end{array}$ & & $\begin{array}{c}0.50 \pm \\
0.07^{*}\end{array}$ & & \\
\hline
\end{tabular}

* Significantly different to the value before injection $(\mathrm{P}<0.05)$.

Number of animals per group $=5$

\section{REFERENCES}

- Amarpa I, Kinjavdekar P, Aithal H, Pawde A and Pratap K. (2002): Analgesic, sedative and hemodynamic effects of spinally administered romifidine in female goats. J. Vet. Med. A. Physiol. Pathol. Clin. Med., 49 (1): 3-8.

- Benson CJ 1999): Physiological effects of pharmalogical agent. Vet. Clinical services, Anesthesia and analgesia (internet).

- Clarke KW (1988): Clinical pharmacology of detomidine in horse. D. Vet. Med. Thesis, Univ. of London.

- Clarke KW and Hall LW (1969): Xylazine: a new sedative for horses and cattle. Vet. Rec., 85:512. 
- Dacia JV and Lewis SM (1975): Practical hematology. $5^{\text {th }}$ Ed., The English language book society and church ill livingstone, p: 21-42.

- Dubowski KM (1962): An O-toluidine method for body fluid glucose dtermination. Cli. Chem., 215-235.

- England GC and Clarke $K W$ (1996): Alpha 2 adrenoceptor agonists in the horse. A review Br. Vet. J., 152 (6): 641-657.

- England GC, Klarke KW and Gossens L (1992): A comparison of sedative effects of three alpha 2 adrenocentor agonists (romifidine, detomidine and xylazine) in the horse. J. Vet. Pharm. Therap., 15 (2): 194-201.,

- Faulkner WR and King JW (1976): Fundamentals of clinical chemistry: determination of creatinine concentration. $2^{\text {nd }}$ Ed., N.W.Tietz (ed.), Saunders, Philadelphia, p.:994.

- Fawcett JK and Scott JF (1960): Estimation of urea. J. Clin. Pathol., 13: 156-159.

- Fierheller EE, Caulkett NA and Bailey JV (2004): A romifidine and morphine combination for epidural analgesia of the flank in cattle. Can. Vet. J., 45 (11): 917-923.

- Freeman SL and England GC (2000): Investigation of romifidine and detomidine for the clinical sedation of horses. Vet. Rec., 147:507-511.

- Freeman SL, Bowen IM, Bettschart-Wolfensberger R, Alibhai HI and England GC (2002): Cardiovascular effect of romifidine in standing horse. Res. Vet. Sci., 72:123-129.

- Hall LW and Clarke KV (1991): Veterinary anesthesia. $9^{\text {th }}$ Ed., Bailliere Tindall, London. 
- Hamm D, Turchi P and Jochle W (1995): Sedative and analgesic effects of detomidine and romifidine in horses. Vet. Rec., april 1 (136):324-327. .

- Hoffman PE (1974): Clinical evaluation of xylazine as a chemical restraining agent, sedative and analgesic in horses. J. Am. Vet. Med. Assoc., 164 (1): 42-45.

- Hsu WH and Hammel SK (1981): Xylazine-induced hyperglycemia in cattle, a possible involvement of alpha 2 adrenergic receptors regulating insulin release. Endocrinology, 109: 825-829.

- Kerr DD, Jones EW, Huggins K and Edwards WC (1972): Sedative and other effects of xylazine given intravenously to horses. Am. J. of Vet. Res., 33: 525-532..

- Kinjavdekar P, Aithal H, Amarpa I, Pawde A, Pratap K. and Singh $\boldsymbol{G}$ (2006): Potential effect of romifidine with lidocaine administration in goats. Small ruminant Research, 64: 293-304.

- Kumar A and Singh H (1978): Xylazine as a sedative and analgesic agent in equine surgery. Ind. J. Health, 17: 7-11.

- Matthew NS, Taylor TS and Hartsfield SM (1997): Anesthesia in donkeys and mules. Eq. Vet. Educ., 9: 198-202.

- Mohsen HM, Marzouk MA and Abuzead SM (2007): Sedative, analgesic, hematological and biochemical effects of romifidine in camels (Camelus dromedaries). Vet. Med. J., Giza, 55 (1): 9-23.

- Nilsfors L, Garmer L and Adolfsson A (1989): sedative and analgesic effects of medetomidine in dogs. An open clinical study. Acta. Vet. Scand. Supp. 85: 155-159. 
- Nouh SR and Abdel-Wahed RE (2000): Romifidine as sedative premedication before thiopentone and ketamine anesthesia in donkey. $7^{\text {th }}$ world congress of veterinary anesthesia, Berne 2000, Sept., 20-23.

- Reitman $S$ and Frankel $S$ (1957): A colorimetric method for determination of serum glutamic oxaloacetic and glutamic pyruvic transaminase. Am. J. Clin. Pathol., 15:56-63..

- SAS (1987: Statistical Analysis System. Users Guide: Statistics. SAS Institute Cary, North Carolina.

- Selmi AL, Barbudo-Selmi GR, Mendes GM, Figueiredo JP and Lins BT (2004): Sedative, analgesic and cardiorespiratory effects of romifidine in cats. Vet. Anesth. Analg., 31 (3): 195-206.

- Shokrey M, Morad H and Khalil I (1976): Studies on the effect of Rompun in sheep. Vet. Med. Review, 2:237-243.

- Short CE (1987): Principal and practice of veterinary anesthesia. $1^{\text {st }}$ Ed., Williams and Wilkins, Baltimore, London, Los Angeles, Sydney.

- Short CE (1992): Alpha 2 agonists in animals. Vet. Practice publishing company, santa Barbara, California, USA.

- Sinclair MD (2003): A review of the physiological effects of alpha 2 agonists related to clinical use of medetomidine in small animal practice. Can. Vet. J., Nov. 44 (11): 88-89.

- Symonds $\boldsymbol{H W}$ (1976): The effect of xylazine upon hepatic glucose production and blood flow rate in lactating dairy cow. Vet. Record, 99:234-236.

- Symonds HW and Mallinson CB (1978): The effect of xylazine and xylazine followed by insulin on blood glucose and insulin in dairy cow. Vet. Record, 102:27-29. 
- Vainio $\boldsymbol{O}$ (1985): Detomidine: a new sedative and analgesic drug for veterinary use. Academic dissertation. College of veterinary medicine, Helsinki, Finland.

- Virtanen $\boldsymbol{R}$ (1989): Pharmacological profiles of medetomidine and its antagonist, atipamizole. Acta Vet. Scand., 85: 29-37.

- Virtanen $R$ and MacDonald E (1985): Comparison of the effects of detomidine and xylazine on some alpha 2 adrenoceptor mediated responses in the central and peripheral nervous system. Eur. J. Pharmacol.,115 (2): 277-284.

- Voeglti K (1988): Studies on sedative and analgesic effect of an alpha 2 adrenoceptor agonist (STH 2130, Boehringer) in horses. DVM Thesis, University of Berne.

- Wagner AE, Muir WW and Hinchcliff KW (1991): The cardiovascular effects of xylazine and detomidine in horses. Vet. Surg., 20 (1): 82.

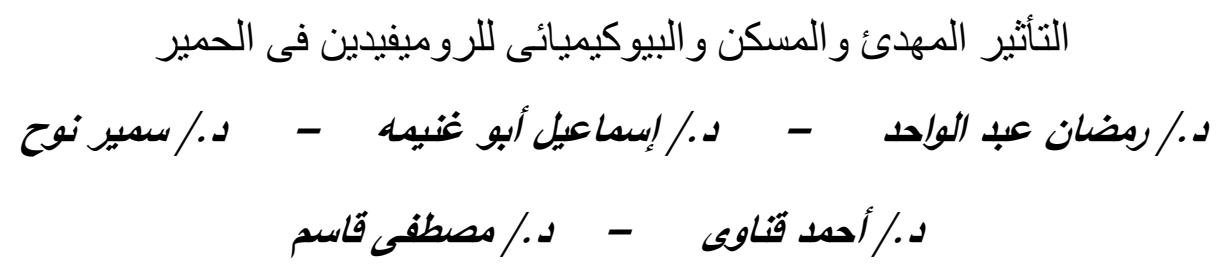

لما كان الروميفيدين كأحدث عقار فى مجموعة منبهات ألفا2 والذى لم يتم استخدامه حقليا فى الحمير فقد استهدفت هذه الدراسة القاء الضوء على التأثير المهدى و الثأثير المسكن للألم وكذلك التغيرات البيوكيميائيه عقب حقن الروميفيدين فى الوريد فى الحمير • نم اجراء هذه الدراسة على عدد 10 من الحمير السليمه اكلينيكيا والتى تراوحت أعمارها بين 4 الى 7 سنوات ووزنها بين 150 و 250 كجم. تم حساب الجرعه اللازمه من الروميفيدين (80 ميكروجرام/كجم مخففه فى 4 سم3 من محلول Kafrelsheikh Vet. Med. J. Vol. 6 No. 1 (2008) 
الملح) وحقنها فى الوريد ثم ملاحظة التغيرات الاكلينيكية مثل معدلات التنفس والنبض ودرجات الحرارة ودراسة التأثير المهدئ والمسكن من خلال التغيرات فى سلوك الحيوان ومدى احساسهوذلك قبل وبعد الحقن. كما تم سحب عينات من الدم لقياس معدل التغير فى وظائف الكبد والكلى وجلوكوز الدم ونسبة الهيموجلوبين و حجم الخلايا المنضغطة وكذلك نسب خلايا الدم البيضاء المختلفة. وقد أوضحت النتائج أن علامات الهدوء والسكينة قد لوحظت على الحمير خلال دقيقتين من الحقن الوريدى للعقار والتى استمرت 86.33 × 0.88 دقيقة. أما فنرة التخدير (فقد الألم) فقد بدأت بعد 2.00 × 0.54 دقيقه واستمرت 68.33 4.40ـ دقيقه مع عدم القدرة على التحكم فى الجسم وعدم الاتزان أحيانا. بملاحظة النأثثر الاكلينيكى وجد أن التغيرات فى النبض والتتفس ودرجة حرارة الجسم كانت حول المعدلات الفسيولوجيه وعادت الى أو بالقرب من هذه المعدلات أثناء أو بعد انتهاء مدة التخدير . كما لوحظ زيادة معدل التبول ونزول اللعاب من الفم. أما التغيرات المسجله فى نتائج تحليل الدم فلم تكن معنويه باستثناء الكرياتينين وسكر الدم. نستخلص من هذه الدراسة أن الروميفيدين له ناثير مهدىه ومسكن قوى وآمن للاستخدام قبل العمليات الجراحيه فى الحمير • 